\title{
PROFIL KOGNITIF BERFIKIR KREATIF SISWA PADA PEMBELAJARAN MATEMATIKA MODEL JIGSAW MELALUI PENDEKATAN DISCOVERY LEARNING
}

\author{
Anike $^{1}$, Hendri Handoko ${ }^{2}$ \\ Mahasiswa Tadris Matematika, IAIN Syekh Nurjati Cirebon ${ }^{1}$ \\ Dosen Tadris Matematika, IAIN Syekh Nurjati Cirebon ${ }^{2}$ \\ Jl. Perjuangan By Pass Sunyaragi Cirebon \\ anike2110@gmail.com ${ }^{1}$, hendri.handokosnj@gmail.com ${ }^{2}$
}

\begin{abstract}
This research aims to determine the cognitive profile of students' creative thinking on learning mathematics model Jigsaw through discovery learning approach. The method used in this research is a quantitative method that is experimental with one-shot case study design study. Student response to the application of jigsaw learning model through discovery learning approach showed a positive response, with average percentage $69.2 \%$ and included in strong category, while for the average mastery of class 78,51. The students' creative thinking ability after being given treatment by applying jigsaw learning model through discovery learning approach has increased. From the observations during the learning at each meeting experienced a significant increase, with the average percentage of $53.81 \%$ included into the good category. Then it can be concluded that the creative thinking ability of class VIII I students in MTs Negeri 1 Kota Cirebon during learning by using jigsaw model through discovery learning approach is said to have good categorization
\end{abstract}

Keywords: Jigsaw learning model. discovery Learning

\begin{abstract}
Abstrak
Penelitian ini bertujuan mengetahui profil kognitif berfikir kreatif siswa pada pembelajaran matematika model Jigsaw melalui pendekatan discovery learning. Metode yang digunakan dalam penelitian ini adalah metode kuantitatif yang bersifat eksperimen dengan desain penelitian one shot case study. Respon siswa terhadap penerapan model pembelajaran jigsaw melalui pendekatan discovery learning menunjukan respon yang positif, dengan rata-rata persentase $69,2 \%$ dan termasuk dalam kategori kuat, sedangkan untuk ketuntasan rata-rata kelas 78,51. Kemampuan berfikir kreatif siswa setelah diberikan perlakuan dengan menerapkan model pembelajaran jigsaw melalui pendekatan discovery learning mengalami kenaikan. Dari hasil pengamatan selama pembelajaran di setiap pertemuannya mengalami peningkatan yang signifikan, dengan persentase rata-rata sebesar 53,81\% termasuk kedalam kategori baik. Maka dapat disimpulkan bahwa kemampuan berfikir kreatif siswa kelas VIII I di MTs Negeri 1 Kota Cirebon selama pembelajaran dengan menggunakan model jigsaw melalui pendekatan discovery learning dikatakan berkategori baik
\end{abstract}

Kata Kunci: Model pembelajaran jigsaw, discovery learning

\section{PENDAHULUAN}

Pendidikan pada umumnya adalah sarana yang paling strategis untuk menanamkan nilai-nilai, ajaran, keterampilan, pengalaman dan sebagainya yang ke dalam diri peserta didik. Pendidikan juga memerlukan fasilitas untuk kelangsungan pembelajaran, untuk melayani kebutuhan peserta didik, atau pendidikan yang seharusnya mengikuti kebutuhan peserta didik.
Pendidikan dikelompokkan menjadi pendidikan formal, pendidikan nonformal, dan pendidikan informal. Ketiganya dalam Undang-Undang Sisdiknas No. 20 Tahun 2003 disebut sebagai jalur-jalur pendidikan (Muhaimin, 2012). Pendidikan yang formal yaitu bersifat terstruktur, berjenjang mulai dari pendidikan dasar, pendidikan menengah dan pendidikan tinggi, pendidikan yang terkait 
usia, waktunya pelaksanaanya yang relatif panjang.

Masalah utama dalam pembelajaran pada pendidikan formal (sekolah) adalah masih rendahnya daya serap peserta didik. Begitu juga dalam pembelajaran matematika. Sebuah laporan dari hasil pengamatan tes dan survey PISA (Programme for International Student Assessment), yang pada tahun 2015 melibatkan 540.000 peserta didik di 70 negara, dianalisis dengan hati-hati dan lengkap menyatakan bahwa performa dalam matematika siswasiswi Indonesia masih tergolong rendah. Berturut-turut rata-rata nilai pencapaian siswa-siswi Indonesia untuk matematika berada pada peringkat 63 dari 69 negara yang dievaluasi, rata-rata nilai Indonesia tersebut tidak berada jauh dengan hasil tes dan survey PISA terdahulu pada tahun 2012 yang juga berada pada kelompok penguasaan materi matematika yang rendah. Matematika itu sendiri merupakan ilmu universal yang mendasari perkembangan teknologi modern dan penting dalam berbagai disiplin ilmu serta mengembangkan daya pikir manusia (Syafwan, 2009).

Menurut (Handoko, 2013) matematika dapat difungsikan untuk mengembangkan kemampuan berpikir yang sistematis, logis, kreatif, disiplin, dan kerjasama yang efektif dalam kehidupan yang modern dan kompetitif sehingga peran matematika sebagai induk ilmu pengetahuan harus mampu pula menghasilkan sumber daya manusia yang berkarakter unggul dan siap saing. Konsekuensi agar tujuan tersebut tercapai maka guru harus dapat menciptakan pembelajaran matematika yang efektif dan efisien dengan strategi dan pemilihan model/metode/strategi pembelajaran yang tepat.

Faktor yang memegang peran penting dalam membantu tercapainya pembelajaran salah satunya adalah pemilihan metode pembelajaran. Menurut Kemp dalam (Rusman, 2013) strategi adalah kegiatan pembelajaran yang dilakukan pendidik dan peserta didik agar tujuan pembelajaran dapat tercapai secara efektif dan efesien. Oleh karena itu, strategi berbeda dengan metode. Strategi lebih kepada sebuah perencanaan yang bertujuan untuk tercapainya sesuatu, sedangkan metode adalah cara yang digunakan untuk melaksanakan strategi pembelajaran
Sedangkan Model pembelajaran menurut Joyce dan Weil sebagaimana dikutip oleh (Rusman, 2013) adalah suatu perencanaan yang dapat digunakan untuk membentuk kurikulum, menyusun bahan-bahan pembelajaran dan membimbing pembelajaran di kelas. Model pembelajaran dapat dijadikan beberapa pilihan oleh guru, maksudnya para guru dapat memilih model pembelajaran yang sesuai materi belajar dan efesien untuk tercapainya tujuan pembelajaran.

Pemilihan metode pembelajaran khususnya dalam pembelajaran matematika harus berhubungan dengan manfaat pentingnya matematika dalam kehidupan sehari-hari. Pembelajaran matematika adalah usaha yang dilakukan oleh guru kepada pesrta didik untuk membangun pemahaman terhadap matematika (Lapis, 2009). Proses membangun pemahaman inilah yang lebih penting daripada hasil belajar sebab pemahaman akan lebih bermakna kepada materi yang dipelajari. Pernyataan yang serupa sama dinyatakan oleh (Sumliyah \& Indriyani, 2017) bahwa pembelajaran matematika merupakan mata pelajaran pokok yang dipelajari sejak tingkat pendidikan dasar karena dapat membentuk pola pemikiran logis, sistematis, kritis dan kreatif.

Pembelajaran harus di desain agar siswa aktif dalam menyelesaikan masalah yaitu dengan menggunakan model pembelajaran yang berpusat pada peserta didik, salah satunya dengan menerapkan model pembelajaran Jigsaw. Model pembelajaran ini dibentuk untuk meningkatkan rasa tanggung jawab siswa terhadap pembelajarannya sendiri dan juga terhadap pembelajaran orang lain. Pada dasarnya, dalam model ini guru membagi suatu informasi ilmu yang besar menjadi komponen-komponen yang lebih kecil (Hamdayama, 2014).

Sedangkan (Rusman, 2013) menyatakan model pembelajaran jigsaw ini mengambil dari cara bekerja sebuah gergaji (zigzag), yaitu siswa melakukan suatu kegiatan pembelajaran dengan cara bekerja sama dengan siswa lain untuk mencapai tujuan bersama.

Pembelajaran kooperatif model jigsaw ini dimodifikasi agar pembelajaran di suatu kelas menjadi lebih menarik, menantang, lebih mudah untuk penguasaan materi dan mengetahui dari mana rumus atau ilmu tersebut ditemukan dengan cara memasukkan 
pendekatan discovery learning di tengahtengah langkah model pembelajaran jigsaw.

\section{KAJIAN PUSTAKA \\ a. Teori Belajar Kognitivisme}

Pernyataan para ahli tentang teori belajar kognitivisme bahwa belajar adalah aktivitas yang melibatkan proses berfikir kompleks. Dimana tindakan seseorang selalu didasarkan oleh kognitif, yaitu perilaku mengenal atau memikirkan situasi dimana perilaku itu terjadi, menurut Wundt dalam buku (Suyono \& Hariyanto, 2012) kognitif adalah sebuah proses pada pembelajaran aktif dan kreatif yang bertujuan membangun struktur melalui pengalaman-pengalaman.

Sedangkan menurut (Prabaningrum, 2016) teori belajar kognitivisme merupakan tingkah laku seseorang ditentukan oleh presepsi atau pemahaman tentang situasi yang berhubungan dengan tujuan-tujuannya. Teori kognitivisme lahir merupakan respon terhadap behaviorisme, yang dipublikasikan pada tahun 1929 oleh Bode, seorang ahli psikologi gestalt. Pandangan geslalt mengenai teori belajar dinyatakan dalam konsep pemelajaran yang disebut teori kognitif. Teori kognitif mencermati bagian-bagian dibalik perilaku untuk menjelaskan pembelajaran berbasis otak. Perbedaan pokok antara seorang gestaltis dengan seorang behavioris, yaitu terletak pada proses pembelajaran. Bagi seorang gestaltis terletak pada individu pembelajaran, sedangkan bagi seorang behvioris terletak pada lingkungan.

Teori belajar kognitif lebih mengutamakan proses belajar daripada hasil belajar. Teori ini mementingkan bahwa perilaku seseorang ditentukan oleh permikiran serta pemahamannya tentang situasi yang berhubungan dengan tujuan belajarnya. Menurut (Suyono \& Hariyanto, 2012) belajar merupakan perubahan pemikiran dan pemahaman yang tidak selalu dapat dilihat sebagai perilaku yang tampak. Teori ini berpandangan bahwa belajar merupakan suatu proses dari dalam diri perserta didik yang mencakup ingatan, pengolahan informasi, rentasi, emosi dan aspek lainya.

Menurut pendekatan kognitif, dalam kaitan teori pemrosesan informasi, unsur terpenting dalam proses belajar adalah pengetahuan yang dimiliki setiap individu sesuai dengan situasi belajarnya. Apa yang telah diketahui siswa akan menentukan apa yang diperhatikanya, dipersepsi olehnya, dipelajari, diingat atau bahkan dilupakan olehnya. Perspektif kognitif membagi jenis-jenis pengetahuan menjadi 3 menurut (Suyono \& Hariyanto, 2012), yaitu sebagai berikut:

a. Pengetahuan deklaratif, yaitu pengetahuan yang dapat dinyatakan dalam bentuk kata atau disebut pula pengetahuan konseptual. Pengetahuan deklaratif rentangnya luas, dapat tentang fakta, konsep, generalisasi, pengalaman pribadi atau tentang hukum dan aturan.

b. Pengetahuan prosedural, yaitu pengetahuan tentang langkah-langkah atau proses-proses yang harus dilakukan atau pengetahuan tentang bagaimana melakukaan. Pengetahuan ini dicirikan oleh adanya praktik dari suatu konsep.

c. Pengetahuan kondisional, yaitu tentang pengetahuan tentang kapan dan mengapa suatu pengetahuan deklaratif dan pengetahuan procedural digunakan. Pengetahuan ini sangat penting karena menentukan kapan penggunaan konsep dan prosdur yang tepat dalam pemecahan masalah.

\section{b. Berfikir Kreatif}

Pembelajaran matematika perlu dibentuk sedemikian rupa sehingga berpotensi mengembangkan kemampuan berfikir kreatif siswa. Ausubel seperti dirujuk oleh Noer (2011) juga menyarankan sebaiknya dalam pembelajaran digunakan pendekatan yang menggunakan metode pemecahan masalah, inquiri dan metode belajar yang menumbuhkan kemampuan berfikir kreatif dan kritis. Kemampuan berfikir kreatif adalah kemampuan untuk mengahsilkan suatu hal yang baru, yaitu sesuatu yang berbeda dengan pemikiran yang dihasilkan dari kebanyakan orang.

Berfikir kreatif dalam matematika biasanya dicirikan dengan intuisi dan kemampuan berfikir analitik yang biasanya dicirikan dengan kemampuan berfikir logis. Dengan demikian, menurut (Istianah, 2013) pengembangan kemampuan berfikir, baik kritis maupun kreatif merupakan suatu hal yang penting untuk dilakukan dan perlu dilatih pada siswa mulai dari jenjang pendidikan dasar sampai jenjang pendidikan menengah. Namun berfikir kreatif bersifat intuitif yang berbeda dengan berfikir kritis (analitis) yang didasarkan pada logika (Nuraini, 2012). 
Menurut Kiesswetter dalam (Ali \& Asrori, 2008) kemampuan berfikir fleksibel yang merupakan salah satu aspek kemampuan berfikir kreatif merupakan kemampuan penting yang harus dimiliki oleh siswa dalam suatu proses pemecahan masalah matematika. Berfikir kreatif matematis mengarah pada kemampuan untuk menghasilkan solusi bervariasi yang bersifat baru terhadap permasalahan matematika yang bersifat terbuka.

Kreatifitas juga merupakan kemampuan seseorang untuk menciptakan sesuatu yang baru atau percampuran dari karya-karya yang sudah ada sebelumnya menjadi suatu karya baru yang dilakukan melalui interaksi dengan lingkungannya untuk menyelesaikan permasalahan dengan mencari alternatif pemecahan melalui cara baru dalam menghadapi suatu malasah atau situasi (Saefudin, 2012). Sejalan dengan (Arini \& Asmila, 2017) dalam jurnalnya menyatakan bahwa berfikir kreatif merupakan pola pikir siswa yang dapat menghasilkan banyak ide bervariasi yang sebelumnya tidak pernah terfikirkan atau tidak ada.

Pada penelitian ini pencapaian hasil belajar dilihat dari kemampuan berpikir kreatif seperti yang dijelaskan oleh Parnes (Nursisto, 2000) yaitu Fluency, Flexibility, Originality, Elaboration, dan Evaluation. Adapun indikator pencapaian kemampuan berpikir kreatif antara lain:

1. Kemampuan berfikir lancar/ kelancaran (Fluency)

a) Siswa mengajukan banyak pertanyaan

b) Siswa dapat menjawab sejumlah jawaban jika ada pertanyaan

c) Mempunyai macam-macam gagasan mengenai suatu masalah

d) Siswa bekerja lebih cepat dan melakukan banyak hal daripada anakanak lain

2. Kemampuan berfikir luwes/keluwesan (flexibility)

a) Memberikan penafsiran terhadap suatu gambar, cerita dan masalah

b) Jika diberikan suatu masalah biasanya memikirkan macam-macam cara yang berbeda untuk menyelesaikannya

3. Kemampuan berfikirasli/keaslian a) Memikirkan masalah-masalah atau halhal yang tidak pernah terpikirkan oleh orang lain

b) Mempertanyakan cara-cara lama dan berusaha memikirkan cara-cara baru

4. Kemampuan merinci/ Kerincian

(Elaboration)

a) Siswa mencari arti yang lebih mendalam terhadap jawaban atau pemecahan masalah dengan melakukan langkahlangkah yang terperinci.

b) Mengembangkan atau memperkaya gagasan orang lain.

5. Keterampilan mengevaluasi (Evaluation)

a) Menentukan pendapat dan bertahan terhadap pendapatnya.

b) Mengkritisi pendapat orang lain yang tidak sejalan dengan aturan

\section{c. Model Pembelajaran Tipe Jigsaw pendekatan Discovery Learning}

Model pembelajaran kooperatif model jigsaw adalah model belajar kooperatif yang lebih mengutamakan pada kerja kelompok siswa dalam bentuk kelompok kecil. Dalam model kooperatif jigsaw ini siswa banyak kesempatan untuk mengemukakan pendapat dan mengolah informasi yang di dapat dan dapat meningkatkan keterampilan berkomunikasi, setiap anggota kelompok bertanggung jawab pada keberhasilan kelompoknya dan ketuntasan bagian materi yang dipelajari dan dapat menyampaikan informasinya kepada kelompok lain (Rusman, 2013).

Pembelajaran model jigsaw ini dikenal juga dengan pembelajaran kooperatif para ahli, karena disetiap kelompok diberikan dengan permasalahan yang berbeda-beda. Tetapi permasalahan yang diberikan setiap kelompoknya sama, setiap perwakilan dalam kelompok yang berbeda membahas materi yang sama, disebut sebagai tim ahli yang di tugaskan membahas permasalahan yang dihadapi, selanjutnya hasil pembahasan yang telah dibahas itu dibawa ke kelompok asal dan disampaikan atau diterangkan kembali pada anggota kelompoknya.

Sedangkan definisi discovery learning menurut (Cahyo, 2013) adalah metode pembelajaran berbasis penemuan yakni metode mengajar yang mengatur pembelajaran sedemikian rupa sehingga anak memperoleh pengetahuan yang sebelumnya belum diketahui tidak melalui pemberitahuan, namun ditemukan oleh siswanya sendiri. Model discovery learning 
juga merupakan pembelajaran dimana proses belajar di dalamnya tidak menyajikan konsep dalam bentuk jadi, tetapi siswa dituntut untuk mengorganisasi sendiri cara belajarnya dalam menemukan suatu konsep (Supraptinah, Budiyono, \& Subanti, 2015).

Kegiatan atau pembelajaran discovery learning dibuat sedemikian rupa, sehingga siswa dapat menemukan konsep-konsep dan prinsipprinsip melalui proses mental pada dirinya sendiri. Saat menemukan konsep, siswa melakukan proses pengamatan, menggolongkan, membuat dugaan, menjelaskan, menarik kesimpulan dan sebagainya untuk menemukan beberapa konsep atau prinsip. Tujuan dilakukanya penemuan ini agar siswa terlibat aktif serta dapat menumbuhkan rasa percaya diri siswa terhadap proses pembelajaran (Mumtainah, 2014).

Menurut Bell dalam buku (Cahyo, 2013) beberapa tujuan spesifik dari pembelajaran discovery learning, yakni sebagai berikut:

1. Dalam proses penemuannya siswa memiliki kesempatan untuk terlibat aktif dalam pembelajaran. Kenyataan menunjukkan bahwa banyak siswa yang antusias dalam pembelajaran ketika penemuan digunakan.

2. Melalui pembelajaran dengan proses penemuan, siswa belajar menemukan pola dalam situasi konkret maupun abstrak, juga siswa banyak menduga informasi tambahan yang diberikan.

3. Siswa juga belajar membuatkan strategi tanya jawab yang tidak mengacu dan menggunakan tanya jawab untuk memperoleh informasi yang bermanfaat dalam menemukan.

4. Pembelajaran dengan penemuan membantu siswa membentuk cara kerja sama yang efektif, saling membagi informasi, serta mendengar dan menerima ide-ide orang lain.

5. Terdapat beberapa fakta yang menunjukkan bahwa keterampilanketerampilan, konsep-konsep dan prinsipprinsip yang dipelajari penemuan lebih bermakna.

6. Keterampilan yang dipelajari dalam proses belajar penemuan dalam beberapa kasus, lebih mudah ditransfer untuk aktivitas baru dan digunakan dalam sitausi belajar yang baru.
Berdasarkan definisi diatas maka pembelajaran yang dilaksanakan pada penelitian ini menggunakan model Jigsaw yang dimodifikasi dengan menerapkan pendekatan discovery learning pada saat tahapan/fase diskusi dengan kelompok ahli.

\section{METODOLOGI}

a. Populasi dalam penelitian ini adalah seluruh siswa kelas VIII MTs Negeri 1 Kota Cirebon. Dengan sampel kelas yang digunakan objek penelitian adalah kelas VIII I tahun ajaran 2017/2018 dengan jumlah siswa 35

b. Desain penelitian yang digunakan dalam penelitian ini adalah one shot case study. Pada desain ini, suatu kelompok diberikan perlakuan dan selanjutnya diobservasi hasilnya (perlakuan adalah sebagai variable independen dan hasil belajar sebagai varabel dependen). Desain ini digunakan sesuai dengan tujuan yang hendak dicapai yaitu ingin pengetahui peningkatan hasil belajar siswa setelah diterapkan model pembelajaran jigsaw melalui pendekatan discovery learning.

c. Alur Pengolahan Data pada penelitian ini meliputi; Pertama, Persiapan yaitu peneliti meyiapkan segala kebutuhan dan instrumen yang akan digunakan untuk penelitian seperti: pengumpulan data, membuat instrumen penelitian, lembar observasi penelitian, membuat instrument angket untuk responden siswa, membuat instrument soal yang akan diberikan untuk siswa. Kedua Pelaksanaan atau pengumpulan data. Tahap ini merupakan penggalian informasi baik melalui penyebaran kuisioner, mengadakan tes, dan data-data lainya yang benar-benar diperlukan dalam penelitian. Namun sebelum soal tes diberikan kepada siswa, soal tes tersebut harus diuji coba instrumen yaitu melalui uji validitas, realibilitas, daya beda dan tingkat kesukaran. Setelah itu barulah soal dianggap valid dan diberikan kepada siswa untuk penelitian. Ketiga tahap pengolahan data, pada tahap ini, peneliti mengelola data-data penelitian yang meliputi mengecek data, mengedit data, tabulasi data dan sebagainya. Selanjutnya data tersebut dianalisis dengan menggunakan teknik analisis yang sesuai dengan data yang diperoleh. Setelah itu, peneliti menarik kesimpulan dari hasil pengolahan data dan analisis data tersebut. 


\section{HASIL DAN PEMBAHASAN}

Proses penelitian ini dilakukan selama 3 bulan. Peneliti ini mengguanakan angket sebagai instrument yang digunakan untuk mengetahui respon siswa dalam penerapan model pembelajaran jigsaw melalui pendekatan discovery learning. Instrumen tes digunakan untuk mengukur hasil belajar matematika siswa dan lembar observasi digunakan untuk mengukur tingkat kreatifitas berfikir siswa. Instrument tersebut disebarkan kepada 35 responden.

\section{a. Deskripsi data hasil respon siswa}

Adapun untuk mengetahui respon siswa terhadap model pembelajaran jigsaw melalui pendekatan discovery learning, peneliti membuat angket yang terdiri dari 30 pernyataan lalu diujicobakan di kelas XI A MTs Negeri 1 Kota Cirebon yang terdiri dari 39 siswa. Uji coba angket ini menggunakan uji validitas dan reabilitas. Setelah diujicobakan hanya 26 item angket yang valid dan 4 item angket dinyatakan tidak valid. Angket tersebut dibagikan terhadap kelas eksperimen yang diberikan perlakuan model pembelajaran jigsaw melalui pendekatan discovery learning.

Tujuan dari disebarkannya angket tentang model pembelajaran jigsaw melalui pendekatan discovery learning adalah untuk mengetahui bagaimana respon siswa terhadap model pembelajaran jigsaw melalui pendekatan discovery learning yang sebelumnya belum pernah digunakan dalam pembelajaran matematika di MTs Negeri 1 Kota Cirebon.

Adapun hasil penyebaran angket respon siswa terhadap penerapan model pembelajaran jigsaw melalui pendekatan discovery learning dengan menggunakan software SPSS 21 berikut penjelasannya:

Tabel 1

Deskriptif Statistik Angket Respon Siswa Descriptive Statistics

\begin{tabular}{|l|l|l|l|l|l|l|}
\hline & N & Min. & Max. & Mean & Std. Dev. & Var. \\
\hline $\begin{array}{c}\text { Respon } \\
\quad \text { Siswa } \\
\text { Valid N } 35 \\
\quad \text { (listwise) }\end{array}$ & 77 & 99 & 90,00 & 6,539 & 42,765 \\
\hline
\end{tabular}

Berdasarkan tabel di atas diperoleh output data dari SPSS 21. Hasil tersebut menunjukkan bahwa sebanyak 35 siswa pada kelas eksperimen dengan respon siswa terhadap penerapan model pembelajaran jigsaw melalui pendekatan discovery learning di dapat skor minimal yang diperoleh siswa sebesar 77 sedangkan skor maksimal yang diperoleh siswa adalah sebesar 99, skor ratarata (mean) diperoleh sebesar 90,00, adapun standar deviasi yang diperoleh adalah 42,765 dan nilai varians sebesar 42,765 .

Hasil angket respon siswa terhadap penerapan model jigsaw melalui pendekatan discovery learning dalam pembelajaran matematika di kelas VIII I MTs Negeri 1 Kota Cirebon semerter 2 tahun pelajaran 2017/2018 disajikan dalam tiap indikator yang dikelompokkan dalam beberapa aspek atau dimensi penelitian. Adapun data tersebut adalah sebagai berikut:

Tabel 2

Rekapitulasi Hasil Angket Respon Siswa Berdasarkan Indikator

\begin{tabular}{|c|c|c|c|}
\hline No & Indikator & $\begin{array}{c}\text { Persentase } \\
\text { Rata-rata } \\
(\%)\end{array}$ & Kategori \\
\hline 1 & $\begin{array}{l}\text { Menumbuhka } \\
\mathrm{n} \text { semangat } \\
\text { belajar }\end{array}$ & $69 \%$ & Kuat \\
\hline 2 & $\begin{array}{l}\text { Menumbuhka } \\
\mathrm{n} \quad \text { minat } \\
\text { belajar siswa }\end{array}$ & $73 \%$ & Kuat \\
\hline 3 & $\begin{array}{l}\text { Aktif bertukar } \\
\text { pendapat }\end{array}$ & $72 \%$ & Kuat \\
\hline 4 & $\begin{array}{l}\text { Aktif dalam } \\
\text { pembelajaran } \\
\text { dikelas }\end{array}$ & $69 \%$ & Kuat \\
\hline 5 & $\begin{array}{l}\text { Mengajarkan } \\
\text { materi kepada } \\
\text { sesama teman }\end{array}$ & $70 \%$ & Kuat \\
\hline 6 & $\begin{array}{l}\text { Memahami } \\
\text { keseluruhan } \\
\text { materi secara } \\
\text { utuh }\end{array}$ & $70 \%$ & Kuat \\
\hline 7 & $\begin{array}{l}\text { Menemukan } \\
\text { konsep materi }\end{array}$ & $69 \%$ & Kuat \\
\hline 8 & $\begin{array}{l}\text { Dapat } \\
\text { merumuskan } \\
\text { masalah }\end{array}$ & $71 \%$ & Kuat \\
\hline 9 & $\begin{array}{l}\text { Dapat } \\
\text { mengumpulka } \\
\mathrm{n} \text { data }\end{array}$ & $66 \%$ & Kuat \\
\hline 10 & $\begin{array}{l}\text { Dapat } \\
\text { menganalisis } \\
\text { data }\end{array}$ & $69 \%$ & Kuat \\
\hline 11 & $\begin{array}{l}\text { Dapat } \\
\text { memverifikasi }\end{array}$ & $66 \%$ & Kuat \\
\hline 12 & $\begin{array}{l}\text { Dapat } \\
\text { menyimpulka } \\
\mathrm{n}\end{array}$ & $66 \%$ & Kuat \\
\hline \multicolumn{2}{|c|}{ Jumlah rata-rata skor } & 830 & \\
\hline \multicolumn{2}{|c|}{$\begin{array}{l}\text { Rata-rata persentase } \\
\text { keseluruhan }\end{array}$} & $69,2 \%$ & Kuat \\
\hline
\end{tabular}

Dari tabel diatas dapat disimpulkan bahwa respon siswa terhadap pembelajaran matematika menggunakan model jigsaw melalui pendekatan discovery learning dari 12 indikator mempunyai prosentase rata-rata $69,2 \%$ dengan kategori kuat. Artinya 
pembelajaran dengan model jigsaw melalui pendekatan discovery learning dapat respon positif dari siswa.

\section{b. Deskripsi data hasil belajar siswa ditinjau dari aspek kognitif}

Hasil belajar merupakan tolak ukur atau patokan yang menentukkan tingkat keberhasilan siswa dalam mengetahui dan memahami suatu materi pelajaran setelah mengalami pengalaman belajar yang diukur melalui tes. Tes tersebut berbentuk essay yang terdiri dari 8 butir soal essay. Setiap soal memiliki bobot skor yang sama yaitu jawaban yang benar diberi skor 10 dan jawaban yang salah diberi skor 0. Sebelum tes ini disebarkan di kelas eksperimen, tes ini diuji cobakan terlebih dahulu menggunakan uji validitas, reabilitas, daya pembeda dan tingkat kesukaran.

Setelah soal diujicobakan hanya terdapat 8 butir soal yang dinyatakan valid atau yang dipakai dalam penelitian dikelas eksperimen. Dalam perhitungan data hasil tes dalam pembelajaran matematika pokok bahasan lingkaran yang telah dilakukan di kelas VIII I, penulis juga menggunakan software SPSS 21 yaitu sebagai berikut:

Tabel 3

Deskripsi Data Tes

\begin{tabular}{|l|l|l|l|l|l|l|}
\hline & $\mathrm{N}$ & Min. & Max. & Mean & Std. Dev. & Vari. \\
\hline $\begin{array}{l}\text { Hasil } \\
\text { Belajar } \\
\text { Valid N } \\
\text { (listwise) }\end{array}$ & 35 & 64 & 96 & 78,51 & 7,972 & 63,551 \\
\hline
\end{tabular}

Diperoleh deskriptif statistik dengan jumlah responden sebanyak 35 siswa. Perhitungan hasil Post-test dikelas eksperimen dengan menggunakan software SPSS 21 diperoleh nilai minimum sebesar 64 artinya hasil belajar siswa yang terkecil secara keseluruhan sebesar 54, nilai maksimum sebesar 96 artinya hasil belajar siswa yang terbesar secara keseluruhan adalah 96, nilai rata-rata (mean) sebesar 78,51, adapun standar deviasi sebesar 7,972 dan nilai variance sebesar 63,551.

Peneliti membuat klasifikasi nilai berdasarkan data distribusi frekuensi kedalam 6 kategori yaitu sangat rendah, rendah, cukup, tinggi dan sangat tinggi. Data distribusi frekuensi digunakan untuk mengetahui hasil belajar siswa. Data distribusi frekuensi menurut
(Riduwan, 2010) dapat dilihat pada tabel berikut:

Tabel 4

Distribusi Frekuensi Tes

\begin{tabular}{|c|c|}
\hline Skala Nilai & Kriteria \\
\hline $85-100$ & Sangat baik \\
\hline $70-84$ & Baik \\
\hline $55-69$ & Cukup \\
\hline $40-54$ & Kurang \\
\hline$<40$ & Kurang sekali \\
\hline
\end{tabular}

Dari tabel distribusi frekuensi di atas, persentase hasil belajar siswa aspek kognitif dalam pembelajaran matematika pada pokok bahasan lingkaran di kelas VIII I MTs Negeri 1 Kota Cirebon sebagai berikut:

Tabel 5

Persentase Nilai Tes Hasil Belajar Siswa Aspek Kognitif

\begin{tabular}{|c|c|c|c|}
\hline Nilai & Frekuensi & $\begin{array}{c}\text { Persentase } \\
(\%)\end{array}$ & Kriteria \\
\hline $85-100$ & 6 & $17 \%$ & SB \\
\hline $70-84$ & 24 & $69 \%$ & $\mathrm{~B}$ \\
\hline $55-69$ & 5 & $14 \%$ & $\mathrm{C}$ \\
\hline $40-54$ & 0 & $0 \%$ & $\mathrm{~K}$ \\
\hline$<40$ & 0 & $0 \%$ & $\mathrm{KS}$ \\
\hline Jumlah & 35 & 100 & \\
\hline
\end{tabular}

Berdasarkan tabel diatas dapat diketahui bahwa hasil belajar aspek kognitif dengan jumlah siswa 35 di kelas VIII I MTs Negeri 1 Kota Cirebon sebesar 17\% dengan kategori hasil belajar aspek kognitif sangat baik, sebesar 69\% dengan hasil belajar aspek kognitif baik, sebesar 14\% dengan kategori hasil belajar aspek kognitif cukup. Dengan demikian dapat disimpulkan bahwa hasil belajar aspek kognitif menyatakan bahwa terdapat 30 siswa mendapatkan nilai antara 70 - 100 yang berarti memenuhi KKM di MTs Negeri 1 Kota Cirebon dengan persentase 86\%.

\section{c. Deskripsi data hasil belajar siswa ditinjau dari kemampuan berfikir kreatif}

Kemampuan berfikir kreatif adalah kemampuan untuk menghasilkan ide atau gagasan baru dalam menghasilkan suatu cara penyelesain masalah, bahkan menghasilkan 
cara baru sebagai solusi alternatif (Lestari \& Yudhanegara, 2017). Untuk mengetahui kemampuan berfikir kreatif siswa dalam pembelajaran matematika model jigsaw melalui pendekatan discovery learning, peneliti membuat lembar observasi yang terdiri dari 5 aspek dan 12 indikator. Lembar observasi tersebut dilakukan pada kelas eksperimen. Berikut dijabarkan hasil observasi dari pertemuan 1 sampai pertemuan 4:

1. Hasil observasi hari pertama diperoleh data total skor dari keseluruhan siswa yaitu sebesar 533 dengan persentase $31,73 \%$, dengan demikian dapat disimpulkan bahwa hasil observasi pada pertemuan pertama ini, kemampuan berfikir kreatif siswa dikategorikan cukup baik.

2. Pada hari kedua hasil observasi ini mengalami kenaikan skor. Skor total dari keseluruhan siswa yang diperoleh yaitu sebesar 702 dengan persentase $41,79 \%$, dengan demikian dapat disimpulkan bahwa hasil observasi pada kedua ini, kemampuan berfikir kreatif siswa dikategorikan cukup baik.

3. Hasil observasi pada pertemuan ketiga juga mengalami penaikan. Skor total dari keseluruhan siswa yang diperoleh yaitu sebesar 867 dengan persentase $51,61 \%$, dengan demikian dapat disimpulkan bahwa hasil observasi pada ketiga ini, kemampuan berikir kreatif siswa dikategorikan baik.

4. Sedangkan pada pertemuan terakhir memperoleh hasil skor yang total dari keseluruhan siswa sebesar 1062 dengan persentase sebesar $63,21 \%$, dengan demikian dapat disimpulkan bahwa kemampuan berfikir kreatif siswa dikategorikan baik.

Tabel 6

Rekapitulasi hasil observasi

\begin{tabular}{|c|c|c|c|}
\hline Pertemuan & $\begin{array}{c}\text { Skor } \\
\text { Total }\end{array}$ & Persentase & Kriteria \\
\hline Pertemuan 1 & 533 & $31,73 \%$ & Cukup baik \\
\hline Pertemuan 2 & 702 & $41,79 \%$ & Cukup baik \\
\hline Pertemuan 3 & 867 & $51,61 \%$ & Baik \\
\hline Pertemuan 4 & 1062 & $63,21 \%$ & Baik \\
\hline Jumlah & 3164 & $53,81 \%$ & Baik \\
\hline
\end{tabular}

Dari data diatas diketahui bahwa hasil persentase pertemuan pertama menunjukkan bahwa siswa memenuhi kelima indikator dari kemampuan berfikir kreatif yang meliputi kelancaran (fluency), Keluwesan (Flexibility), keaslian (originality), merinci (Elaboration) dan evaluasi (Evaluation) sebesar 31,73\% dengan kriteria cukup baik. Pertemuan kedua mengalami peningkatan dengan persentase sebesar 41,79\% dengan kriteria cukup baik. Pertemuan ketiga memperoleh persentase sebesar 51,61\% dengan kriteria baik dan pertemuan terakhir yaitu pertemuan keempat memperoleh persentase sebesar $63,21 \%$ dengan kriteria baik.

Selama proses pembelajaran dengan penerapan model jigsaw melalui pendekatan discovery learning, tingkat kemampuan berfikir kreatif siswa dalam pembelajaran matematika mengalami peningkatan yang baik karena setiap pertemuan mengalami peningkatan dan persentase yang tertinggi berada pada pertemuan akhir. Hasil rata-rata persentase dari keseluruhan pertemuan sebesar 53,81\%, artinya dapat dikatakan bahwa kemampuan berfikir kreatif siswa pada kelas VIII I secara keseluruhan dikatakan baik.

\section{KESIMPULAN DAN SARAN}

\section{a. Kesimpulan}

Berdasarkan tujuan, pengolahan data dan hasil penelitian mengenai pengaruh penerapan model pembelajaran jigsaw melalui pendekatan discovery learning terhadap hasil belajar matematika siswa serta hasil pembahasan dan pengujian hipotesis, diperoleh kesimpulan sebagai berikut:

1. Respon siswa terhadap penerapan model pembelajaran jigsaw melalui pendekatan discovery learning menunjukan respon yang positif, dari data yang diperoleh dalam kegiatan pembelajaran dapat diketahui bahwa rata-rata skor respon siswa terhadap penerapan model pembelajaran jigsaw melalui pendekatan discovery learning sebesar 90,00 artinya rata-rata respon siswa dalam kategori baik. Rata-rata siswa menyatakan bahwa mereka lebih menyukai pembelajaran matematika dengan menerapkan model jigsaw melalui pendekatan discovery learning daripada metode pembelajaran yang lain adalah sebesar $69,2 \%$ termasuk dalam kategori kuat. Jadi siswa lebih menyukai pembelajaran dengan menerapkan model jigsaw melalui pendekatan discovery learning daripada metode yang lain, karena model pembelajaran jigsaw melalui pendekatan discovery learning menciptakan suasana belajar yang menyenangkan, belajar 
matematika lebih menarik dan mudah dipahami, serta dapat memecahkan masalah dengan sendirinya dan memiliki rasa tanggung jawab, sehingga memotivasi siswa untuk belajar.

2. Hasil belajar matematika siswa aspek kognitif setelah diberikan perlakuan dengan menerapkan model pembelajaran jigsaw melalui pendekatan discovery learning menjadi lebih baik. Hal ini dapat dilihat dari skor rata-rata hasil belajar siswa sebesar 78,51, dari keseluruhan siswa yang diberikan tes ini memperoleh nilai antara 70-100 dengan kategori baik yang memenuhi ketuntasan KKM.

3. Hasil belajar matematika ditinjau dari kemampuan berfikir kreatif siswa setelah diberikan perlakuan dengan menerapkan model pembelajaran jigsaw melalui pendekatan discovery learning mengalami kenaikan, dari hasil pengamatan selama pembelajaran di setiap pertemuanya mengalami peningkatan yang signifikan, dengan porsentase rata-rata sebesar $53,81 \%$ termasuk kedalam kategori baik, maka dapat disimpulkan secara keseluruhan kemampuan berfikir kreatif siswa kelas VIII I di MTs Negeri 1 Kota Cirebon dikatakan sudah baik selama menerapkan model pembelajaran jigsaw melalui pendekatan discovery learning.

\section{b. Saran}

Berdasarkan hasil penelitian yang telah dilakukan, maka disampaikan beberapa saran sebagai berikut:

1. Dalam upaya meningkatkan hasil belajar siswa pada pembelajaran matematika, penerapan model pembelajaran jigsaw melalui pendekatan discovery learning merupakan salah satu metode dan media pembelajaran yang efektif karena memberikan kesempatakan kepada siswa untuk terlibat secara aktif dalam proses pembelajaran dan proses pembelajaran lebih bermakna serta menyenangkan bagi siswa. Oleh karena itu, penerapan model pembelajaran jigsaw melalui pendekatan discovery learning dapat dijadikan bahan pertimbangan oleh guru sebagai salah satu inovasi dan alternatif metode dan media pembelajaran pada pembelajaran matematika.

2. Penelitian yang telah dilakukan ini terbatas pada variabel penelitian, sasaran penelitian hanya pada pokok bahasan lingkaran. Untuk itu diharapkan kepada kepada peneliti lain untuk memperluas permasalahan penelitian yang akan diteliti, seperti kemampuan kemandirian matematika siswa, kemampuan berfikir kritis dan sebagainya. Sasaran penelitian, dapat dilakukan pada sasaran penelitian yang lebih luas misalnya memperluas permasalahan, menemukan ide-ide baru, menumbuhkan sikap positif pada matematika dan sebagainya, untuk pokok bahasan, peneliti lain dapat memilih pokok bahasan yang berbeda seperti pokok bahasan bangun datar, bangun ruang dan sebagainya. Hal tersebut diharapkan dapat mengungkapkan fakta baru mengenai hal-hal yang dapat dipengaruhi oleh model pembelajaran jigsaw melalui pendekatan discovery learning.

\section{DAFTAR PUSTAKA}

Ali, M., \& Asrori, M. (2008). Psikologi Remaja Perkembangan Peserta Didik. Jakarta: PT. Bumi Aksara.

Arini, W., \& Asmila, A. (2017). Analisis Kemampuan Berfikir Kreatif Pada Materi Cahaya Siswa Kelas VIII SMP XAVERIUS Kota Lubuklinggau. Science and Physics Education Journal (SPEJ), 1(1), 23-38.

Cahyo, A. N. (2013). Panduan Aplikasi TeoriTeori Belajar Mengajar Teraktual dan Terpopuler. Jogyakarta: DIVA Press.

Hamdayama, J. (2014). Model dan Metode Pembelajaran Kreatif. Jakarta: PT Ghalia Indonesia.

Handoko, Hendri. (2013). Pembentukan Kemampuan Berpikir Kreatif Pada Pembelajaran Matematika Model SAVI Berbasis Discovery Strategy di Laboratorium Teezania. Prosiding Seminar Nasional Matematika VII UNNES, 26 oktober 2013 : 287-192.

Istianah, E. (2013). Meningkatkan Kemampuan Berfikir Kritis dan Kreatif Matematika Dengan Pendekatan Model Eliciting Activities (MEas) Pada Siswa SMA. Jurnal Ilmiah Program Studi Matematika STKIP Siliwangi, 2(1), 43-54. 
Lapis. (2009). Pembelajaran Matematika MI. Surabaya: Amanah Pustaka.

Lestari, K., \& Yudhanegara, M. (2017). Penelitian Pendidikan Matematika. Bandung: Refika Aditama.

Muhaimin. (2012). . Pengembangan Kurikulum Pendidikan Agama Islam di Sekolah, Madrasah dan Perguruan Tinggi. Jakarta: PT Rajagrafindo Persada.

Mumtainah, I. (2014). Pengaruh Metode Pembelajaran Guided Discovery Terhadap Pemahaman dan Disposisi matematika di Kelas VII MTs Salafiyah Kota Cirebon Pada Pokok Bahasan Segi Empat. IAIN Syekh Nurjati Cirebon, Tadris Matematika, Cirebon.

Noer, S. H. (2011). Kemampuan berfikir Kreatif Matematis dan Pembelajaran Matematika Berbasis Masalah OpenEnded. Jurnal Pendidikan Matematika, 5(1), 104 - 111.

Nuraini, S. (2012). Peningkatan Kemampuan Berfikir Kreatif Matematika Siswa Melalui Model Reciprocal Teaching di Kelas VII SMPN 20 Pekanbaru. Universitas Islam Negeri Sultan Syarif Kasim, Fakultas Tarbiyah dan Keguruan, Pekanbaru.

Nursisto. (2000). Kiat Menggali Kreativitas. Yogyakarta: PT Mitra Gama Widya.

Prabaningrum, T. (2016). Penerapan Model Pembelajaran Kooperatif Tipe Jigsaw untuk Meningkatkan Motivasi Belajar dan Hasil Belajar Sosiologi Siswa Kelas XI IPS 2 SMAN 1 Sioarjo Wonogiri Tahun Pelajaran 2015/2016. Universitas Sebelas Maret, Fakultas Keguruan dan Ilmu Pendidikan, Surakarta.

Riduwan. (2010). Dasar-dasar Statistika. Bandung: Alfabeta.

Rusman. (2013). Model-Model Pembelajaran. Bandung: PT Rajagrafindo Persada.

Saefudin, A. A. (2012). Pengembangan Berfikir Kreatif Siswa dalam Pembelajaran
Matematika dengan Pendekatan

Pendidikan matematika Realistik. Yogyakarta: Universitas PGRI Yogyakarta.

Sumliyah, \& Indriyani. (2017). Penerapan Model Pembelajaran Assure dalam Meningkatkan Kemampuan Berfikir Kritis Siswa SMP. EduMa, 6(2), 53-58.

Supraptinah, U., Budiyono, \& Subanti, S. (2015). Eksperimentasi Model Pembelajaran Discovery Learning, Problem Based Learning, dan Saintifik Terhadap Kemampuan pemecahan Masalah Matematika ditinjau dari Kemandirian Belajar Siswa. Jurnal Elektronik Pembelajaran Matematika, 3 (10), 1138-1149.

Suyono, \& Hariyanto. (2012). Belajar dan Pembelajaran. Bandung: Remaja Rosdakarya.

Syafwan. (2009). Meningkatkan Hasil Belajar Matematika Siswa melalui Strategi Pembelajaran Kooperatif Tipe Tutor Sebaya untuk Siswa Kelas VII-A SMP Negeri 2 Poso Pesisir. Jurnal Kreatif Tadulako Online, 4(4), 227-238 